\title{
The influence of dietary phosphorus intake on the rate of bone metabolism in sheep
}

\author{
BY V. R. YOUNG,* J. R. LUICK AND G. P. LOFGREEN \\ Department of Animal Husbandry, University of California, Davis, \\ California, USA
}

(Received I5 December I965-Accepted I5 May I966)

\begin{abstract}
I. A combination of balance and isotope techniques was used to determine the influence of phosphorus depletion on the size of the exchangeable calcium pool and on the rates of $\mathrm{Ca}$ deposition in and removal from the whole skeleton of sheep. 2 . The exchangeable $\mathrm{Ca}$ pool was reduced in size in the depleted sheep to approximately $50 \%$ of that in the controls. 3 . The rates of $\mathrm{Ca}$ deposition in and removal from bone were reduced by $\mathrm{P}$ depletion and the rate of $\mathrm{Ca}$ transfer from the pool was reduced slightly. 4. The turnover rates of the exchangeable $\mathrm{Ca}$ pool and bone $\mathrm{Ca}$ in sheep appear to be similar to values published for man.
\end{abstract}

In view of the evidently close relationship between the skeleton and the metabolism of calcium and phosphorus, a number of investigators have used radioactive tracer techniques to measure the various processes involved in the growth and remodelling of the skeleton (see Aubert, Bronner \& Richelle, r963, for a review of the literature), and to measure the influence of dietary and metabolic factors on these processes. Thus, Milhaud, Remagen, Gomes de Matos \& Aubert (1960) have shown that in rachitic rats rates of bone formation and bone resorption are markedly lower than normal. Similar results have been obtained in human subjects with rickets (Bauer, Carlsson \& Lindquist, 1956).

Recently Bronner, Richelle, Saville, Nicholas \& Cobb (1963), using a kinetic approach to the study of $\mathrm{Ca}$ metabolism, showed that a significant positive correlation existed between the rates of $\mathrm{Ca}$ absorption from the intestine and $\mathrm{Ca}$ deposition in the bone. The relationship suggests that at high rates of intestinal absorption a relatively large amount of $\mathrm{Ca}$ was deposited in the skeleton. However, as Bronner (1964) points out, $\mathrm{Ca}$ absorption may not be an independent variable and may vary with the intensity of $\mathrm{Ca}$ metabolism. Support for this view might be obtained from the studies of Kimberg, Schachter \& Schenker (I96I), who showed that low-Ca diets enhanced Ca transfer in preparations of everted gut sacs from rats.

The influence of a low $P$ intake together with an adequate concentration of dietary $\mathrm{Ca}$ and vitamin $\mathrm{D}$ has not been studied by means of a kinetic approach, as used in the investigations cited above. Since ruminant diets usually supply adequate $\mathrm{Ca}$ but are often limiting in $\mathrm{P}$ (for review see Hill, 1961), it appeared desirable to obtain information on the influence of $\mathbf{P}$ depletion on the rates of $\mathrm{Ca}$ deposition and removal from the skeleton. Therefore, during a detailed investigation of the influence of $\mathbf{P}$ depletion on the absorption and excretion of $\mathrm{Ca}$ and $\mathrm{P}$ in sheep, the results of which

* Present address: Department of Nutrition \& Food Science, Massachusetts Institute of 'Technology, Cambridge, Massachusetts, USA. 
will be reported separately, a kinetic study of skeletal Ca metabolism was made in five sheep with the aid of ${ }^{45} \mathrm{Ca}$ and ${ }^{32} \mathrm{P}$.

The size of the rapidly exchangeable $\mathrm{Ca}$ pool and the rates of deposition of $\mathrm{Ca}$ in and its removal from bone appeared to be reduced after a prolonged period of $\mathbf{P}$ depletion.

\section{EXPERIMENTAL}

\section{Animals and dietary treatment}

Three wether lambs were offered a diet low in $\mathrm{P}$ and adequate in $\mathrm{Ca}(0.073 \% \mathrm{P}$, $0.48 \% \mathrm{Ca}$ on a dry-matter basis) and three wether lambs were offered a diet adequate in both $\left(0.40 \% \mathrm{P}, 0.40 \% \mathrm{Ca}\right.$ on a dry-matter basis) for $\mathrm{I}_{42}$ days. The composition of the diets is shown in Table I. One lamb refused to eat the low-P diet before the experiment was completed and hence was excluded from the study. All animals were about 6 months of age at the beginning of the experiment and were of White-Face cross-breeding. Ergocalciferol was added to the diets at the rate of $330 \mathrm{i} . \mathrm{u} . / \mathrm{kg}$ diet on the basis of the recommendations made by Andrews \& Cunningham (I945-6); the sheep had direct access to sunlight. After the period of $\mathrm{P}$ depletion the sheep were placed in metabolism stalls and given $\mathrm{Ca}$ and $\mathrm{P}$ in the amounts shown in Table 2. A 4-day preliminary period, during which the animals became accustomed to the stalls and diets, was allowed before the metabolism study began. All the sheep consumed the complete daily allowance of food; food was offered at $07.00 \mathrm{~h}$ and at $19.00 \mathrm{~h}$.

Table r. Composition (\%) of the diet low in phosphorus and of the control diet given to sheep for 142 days before the metabolism trial

\begin{tabular}{lcc}
\multicolumn{1}{c}{ Constituent } & Low-P & Control \\
Beet pulp, dried & 62.0 & 60.9 \\
Molasses & $10 \cdot 0$ & $10 \cdot 0$ \\
Barley straw & $10 \cdot 0$ & $10 \cdot 0$ \\
Pearl starch & $16 \cdot 0$ & 16.0 \\
Urea & $\mathrm{I} \cdot 5$ & $\mathrm{I} \cdot 5$ \\
Salt containing trace minerals* & 0.5 & 0.5 \\
Vitamin A and D concentratet & + & + \\
$\mathrm{NaH}_{2} \mathrm{PO}_{4}$, anhydrous & - & $\mathrm{I} \cdot \mathrm{I}$
\end{tabular}

* Supplied not less than: 96.5\% NaCl, 0.2\% Mn, 0.16\% Fe, $0.033 \% \mathrm{Cu}, 0.01 \% \mathrm{Co}, 0.007 \% \mathrm{I}$, $0.005 \% \mathrm{Zn}$ (Morton Salt Co., Chicago).

+ Added to supply 2640 i.u. vitamin $A$ and $33 \circ$ i.u. ergocalciferol $/ \mathrm{kg}$ diet.

\section{Procedure}

After the preliminary period each sheep was injected subcutaneously with $2.8 \mathrm{mc}$ ${ }^{45} \mathrm{Ca}$ and $4.9 \mathrm{mc}{ }^{32} \mathrm{P}$. The isotope solutions were adjusted to near neutrality with weak sodium hydroxide before injection and one isotope was given on each side of the vertebral column in the area of the tail-head. Complete urine and faecal collections were made during the $12 \mathrm{~h}$ period following injection and at $24 \mathrm{~h}$ intervals during the subsequent 7 days. Blood samples were taken by jugular puncture at $\mathrm{I}, 6,12,36,60$, 108, $132,180,216,288$ and $360 \mathrm{~h}$ after injection of the isotopes. 


\section{Analytical methods}

Faeces were ashed at $55^{\circ}$ and extracted with hot $\mathrm{HCl}$ (approx. $6 \mathrm{~N}$ ). Urine samples were treated in the same way after evaporation to dryness. Dried samples of the ash solutions were treated with a few drops of $\mathrm{H}_{2} \mathrm{O}_{2}$ and concentrated $\mathrm{H}_{2} \mathrm{SO}_{4}$, which appeared to prevent an interference by silica during the determination of $\mathrm{P}$. Ca was determined by the method of Clark \& Collip (1925) and $\mathrm{P}$, with $\mathrm{FeSO}_{4}$ as the reducing agent, by the method of Fiske \& Subbarow (1925). Serum $\mathrm{Ca}$ was determined by a macro-modification of the method suggested by Watson \& Rogers ( 1963 ) and serum $P$ by the method of Fiske \& Subbarow (x925).

The activities of ${ }^{45} \mathrm{Ca}$ and ${ }^{32} \mathrm{P}$ in the samples were determined by the method of Comar, Hansard, Hood, Plumlee \& Barrentine (I95I) with a specially constructed aluminium filter $\left(5^{\mathrm{I}} \mathrm{mg} / \mathrm{cm}^{2}\right)$ and an automatic gas-flow Geiger-Müller counter.

\section{Kinetic analysis}

Details of the method of kinetic analysis used in this study have been discussed previously by Aubert et al. (I963). The values were analysed by the second of two simplified methods described by these workers.

From 60 to $180 \mathrm{~h}$ after injection the specific activity of the serum $\mathrm{Ca}$ decreased according to a simple exponential relationship with time. This portion of the curve was used for calculating the size of the exchangeable Ca pool and the rate of transfer of $\mathrm{Ca}$ from this pool. The exchangeable $\mathrm{Ca}$ pool is designated $E$ in this paper. Measures of the rates of excretion of metabolic faecal $\mathrm{Ca}$ and $\mathrm{P}$ were required in order to undertake the kinetic analysis. The formula employed in the calculation of metabolic faecal excretion of $\mathrm{Ca}$ and $\mathrm{P}$ is similar to one derived by Bronner (I964) from the kinetic analysis by Aubert et al. $(1963)$ and was as follows:

$$
v_{f}=\frac{v_{u} \times\left(R_{F}\right)}{R_{u}}
$$

where $v_{f}=$ metabolic faecal excretion of $\mathrm{Ca}$ or $\mathrm{P}(\mathrm{g})$ in $(\mathbf{1} 80-t) \mathrm{h} ; v_{u}=$ urinary $\mathrm{Ca}$ or $\mathrm{P}(\mathrm{g})$ from time of injection to $(\mathrm{1} 8 \mathrm{o}-t) \mathrm{h}$, where $t=$ number of hours lag between injection and peak faecal specific activity; $R_{F}=$ total radioactivity in faeces for the $\mathrm{r} 80 \mathrm{~h}$ period after the injection; and $R_{u}=$ total radioactivity in urine from the time of injection to $(180-t) \mathrm{h}$, where $t=$ number of hours lag between injection and the peak specific activity of the faeces.

Simesen, Lunaas, Rogers \& Luick (1962) have used a similar method of calculation in their study of endogenous magnesium excretion in calves.

\section{RESULTS}

Table 2 shows the mean daily intake, absorption and balance of $\mathrm{Ca}$ and $\mathrm{P}$ in the sheep studied. In Table 3 the results are given of the kinetic analysis of the rate of skeletal metabolism in the two sheep which had been previously depleted of their stores of body $\mathrm{P}$ and in the three control sheep. The size of the rapidly exchangeable Ca pool $(E)$ was substantially reduced after $\mathrm{P}$ depletion. In the two depleted sheep the 
values, $I I \cdot I$ and $I I \cdot 7 \mathrm{~g}$, were almost identical. The average size of the pool in the control sheep was $20.8 \mathrm{~g}$ or approximately double that in the depleted sheep. If the amount of skeletal $\mathrm{Ca}$ is assumed to be approximately $335 \mathrm{~g}$ in each of these control sheep (mean live weight $43 \mathrm{~kg}$ ), as estimated by extrapolation from the values of Benzie, Boyne, Dalgarno, Duckworth \& Hill (r959), then the exchangeable Ca pool would approximate to $6 \%$ of the total body $\mathrm{Ca}$. The rates of deposition $\left(V_{0+}\right)$ of $\mathrm{Ca}$ in and its removal $\left(V_{0}\right)$ from bone also appeared to be reduced as a result of the prolonged period of $\mathrm{P}$ depletion. Though it is appreciated that the present results are based on relatively few observations, they also suggest that a decreased total transfer rate $\left(V_{r}\right)$ of $\mathrm{Ca}$ from the Ca pool resulted from offering a diet low in $\mathrm{P}$ for a 142 -day period.

Table 2. Mean daily dietary intake, absorption and balance $(g)$ of calcium and phosphorus in $P$-depleted and control sheep over the experimental period of $\mathrm{I} 80 \mathrm{~h}$

\begin{tabular}{|c|c|c|c|c|c|c|}
\hline \multirow[b]{2}{*}{$\begin{array}{c}\text { Sheep } \\
\text { no. }\end{array}$} & \multicolumn{3}{|c|}{$\mathrm{Ca}$} & \multicolumn{3}{|c|}{$\mathrm{P}$} \\
\hline & Intake & Absorbed* & Balance & Intake & Absorbed* & Balance \\
\hline \multicolumn{7}{|c|}{ P-depleted sheep } \\
\hline I & $3 \cdot 29$ & 0.73 & 0.03 & 0.30 & 0.27 & -0.08 \\
\hline 2 & 4.0 & 0.77 & -0.11 & 0.36 & 0.14 & -0.13 \\
\hline \multicolumn{7}{|c|}{ Control sheep } \\
\hline 4 & $2 \cdot 94$ & 0.54 & 0.23 & $1 \cdot 65$ & I'I I I & -0.04 \\
\hline 5 & $3 \cdot 14$ & 0.88 & 0.23 & $1 \cdot 70$ & $x \cdot 05$ & 0.20 \\
\hline 6 & $3 \cdot 33$ & $I \cdot I 6$ & 0.83 & $\mathrm{I} \cdot 8 \mathrm{I}$ & $I \cdot 12$ & 0.25 \\
\hline
\end{tabular}

Table 3. Influence of phosphorus depletion on the size of the exchangeable calcium pool and rates of $C a$ deposition and removal in the whole body of sheep

\begin{tabular}{|c|c|c|c|c|c|}
\hline $\begin{array}{l}\text { Sheep } \\
\text { no. }\end{array}$ & $\mathbf{P}$ status & $\begin{array}{c}\text { Exchangeable } \\
\text { Ca pool }(E) \\
(\mathrm{g})\end{array}$ & $\begin{array}{c}V_{0+} * \\
(\mathrm{~g} \mathrm{Ca} / \mathrm{day})\end{array}$ & $\begin{array}{c}V_{0-\dagger} \\
\text { (g Ca/day) }\end{array}$ & $\begin{array}{c}V_{T} \downarrow \\
\text { (g Ca/day) }\end{array}$ \\
\hline I & Depleted & II I I I & $2 \cdot 75$ & $2 \cdot 72$ & $3 \cdot 19$ \\
\hline 2 & Depleted & $15 \cdot 7$ & $3 \cdot 39$ & $3 \cdot 51$ & $4 \cdot 27$ \\
\hline 4 & Control & $20 \cdot 1$ & $4: 33$ & $4 \cdot 10$ & $4 \cdot 64$ \\
\hline 5 & Control & I $8 \cdot 8$ & 5.01 & $4 \cdot 78$ & $5 \cdot 66$ \\
\hline 6 & Control & 23.5 & $4 \cdot 89$ & 4.06 & 5.21 \\
\hline
\end{tabular}

\section{DISCUSSION}

The average size of the exchangeable $\mathrm{Ca}$ pool in the control sheep was found to be $20.8 \mathrm{~g}$, which, as suggested in the previous section, appears to approximate to $6 \%$ of the total body $\mathrm{Ca}$. This value may be compared with that of $3.9 \%$ obtained in rats (Bauer, Carlsson \& Lindquist, 1955), 2-5\% in the mature cow (Hansard, Comar \& Davis, 1954), and approximately $0.5 \%$ in young, adult, human subjects (Bronner \& Harris, 1956). The value for the depleted sheep is likely to be less than that for the control sheep, since $\mathrm{P}$ depletion resulted in a $50 \%$ reduction in the size of the ex- 
changeable $\mathrm{Ca}$ pool and an approximate $33 \%$ reduction of the total skeletal ash weight during the same time period for similar sheep (Young, unpublished results).

The size of the exchangeable Ca pool and the rates of Ca deposition (bone anabolism) as determined in this experiment may be compared with some recent estimates made in the cow. Using the method of Bauer et al. (1955), Garner, Jones \& Sansom (1960) estimated the exchangeable $\mathrm{Ca}$ pool to be $4 \mathrm{I} \mathrm{g}$ and the rate of $\mathrm{Ca}$ deposition to be $1 \cdot 4 \mathrm{~g} \mathrm{Ca} / \mathrm{h}$. This rate compares with that of $0 \cdot 198 \mathrm{~g} \mathrm{Ca} / \mathrm{h}$ for the control sheep in the present study. In a more recent study, involving use of the method proposed by Bauer et al. (1955), Manston (1964) reported an exchangeable Ca pool of $18 \mathrm{~g}$ and a bone deposition rate of $0.679 \mathrm{~g} \mathrm{Ca} / \mathrm{h}$ in the dairy cow, values which are substantially lower than those given by Garner et al. (1960). As far as the authors are aware, these are the only values obtained by similar analyses in ruminant animals. In studies with dairy cows, Luick, Boda \& Kleiber (1957) determined what they called the 'mobilizable calcium pool', which varied in size from 36 to $62 \%$ of the total body Ca. The transfer rate $\left(V_{T}\right)$ from the exchangeable pool did not vary with $\mathrm{Ca}$ intake and amounted to $26 \mathrm{~g} \mathrm{Ca} /$ day. Unfortunately, direct comparison between these findings and the results given in the present paper cannot be made, since the estimate of Luick et al. (1957) undoubtedly relates to a pool quite distinct from the rapidly exchangeable $\mathrm{Ca}$ pool $(E)$ as defined in the present study.

If the distinction between labile and stable fractions of the bone mineral has functional significance, it is not surprising that the manipulation of dietary $\mathrm{P}$ affects the size of the labile Ca pool. This has already been pointed out by Bronner (1964). It is also of interest that Aikawa, Reardon \& Harms (1962) found a decrease in the exchangeable $\mathrm{Mg}$ pool in rats given a Mg-deficient diet. Since it is not feasible to use a similar approach for the determination of the size of the exchangeable skeletal $P$ pool (Bauer et al. 1955), owing to interference by the large amounts of extraskeletal phosphates, a comparison of the sizes of the exchangeable $\mathrm{Ca}$ and $\mathrm{P}$ pools was not made.

\section{Table 4. Turnover rates (day $\left.{ }^{-1}\right)$ of the exchangeable calcium pool $\left(K_{T}\right)$ and of the bone $\mathrm{Ca}\left(K_{0+}\right)$ of selected species}

$\begin{array}{lccc}\text { Species } & K_{T}{ }^{*} & K_{0+} \dagger & \text { Reference } \\ \text { Man } & 0.23 \circ & 0.151 & \text { Lemaire \& Bronner (1963) } \\ \text { Rat } & 3.686 & 3.245 & \text { Lemaire \& Bronner (I963) } \\ \text { Sheep } & 0.250 & 0.229 & \text { Present paper, control sheep } \\ \text { Sheep } & 0.326 & 0.268 & \text { Present paper, depleted sheep } \\ & * K_{T}=\frac{\text { total Ca loss from exchangeable Ca pool }\left(V_{T}\right)}{\text { exchangeable Ca pool }(E)} \\ & +K_{0+}=\frac{\text { Ca deposited in skeleton }\left(V_{0++}\right)}{\text { exchangeable Ca pool }(E)}\end{array}$

The overall pool turnover rate, $K_{T}=V_{T} / E$, and the bone turnover rate, $K_{0+}=V_{0+} / E$, calculated for the control sheep, compare closely with the values reported for man, as shown in Table 4. From a comparison of the values given in this paper it might be suggested that the exchangeable $\mathrm{Ca}$ pools, as determined by the isotope techniques employed in this experiment and those of Lemaire \& Bronner 
(1963), in sheep and in man closely correspond to each other. Bronner (1964) implies that the difference in the rate constants between the rat and man may result from the fact that the exchangeable $\mathrm{Ca}$ pool, designated as $E$, in the rat corresponds to only a portion of the pool in man. The present results suggest that the difference between the rate constants in the sheep and in the rat may also be explained on this basis.

The authors gratefully acknowledge the assistance of Mr John Bryan and Miss Betty Chew.

\section{REFERENCES}

Aikawa, J. K., Reardon, J. Z. \& Harms, D. R. (1962). F. Nutr. 76, 90.

Andrews, E. D. \& Cunningham, I. J. (1945-6). N.Z. $\mathscr{~ l l ~ S c i . ~ T e c h n o l . ~ 2 7 , ~ S e c t . ~ A , ~ p . ~} 223$.

Aubert, J.-P., Bronner, F. \& Richelle, L. J. (1963). J. clin. Invest. 42, 885.

Bauer, G. C. H., Carlsson, A. \& Lindquist, B. (I955). K. Fysiogr. Sällsk. Lund. Förh. 25, I.

Bauer, G. C. H., Carlsson, A. \& Lindquist, B. (1956). Metabolism 5, 573.

Benzie, D., Boyne, A. W., Dalgarno, A. C., Duckworth, J. \& Hill, R. (1959). F. agric. Sci., Camb. 52, I.

Bronner, F. (1964). In Mineral Metabolism. Vol. 2, Part A, Ch. 20. [C. L. Comar and F. Bronner, editors.] New York and London: Academic Press Inc.

Bronner, F. \& Harris, R. S. (1956). Ann. N.Y. Acad. Sci. 64, 3 I 4.

Bronner, F., Richelle, L. J., Saville, P. D., Nicholas, J. A. \& Cobb, J. R. (1963). F. clin. Invest. $42,898$.

Clark, E. P. \& Collip, J. B. (1925). F. biol. Chem. 63, 46r.

Comar, C. L., Hansard, S. L., Hood, S. L., Plumlee, M. P. \& Barrentine, B. F. (I95I). Nucleonics 8, I9.

Fiske, C. H. \& Subbarow, Y. $(1925)$. $\%$. biol. Chem. 66, $3^{6} 5$.

Garner, R. J., Jones, H. G. \& Sansom, B. F. (1960). Biochem. F. 76, 572.

Hansard, S. L., Comar, C. L. \& Davis, G. K. (1954). Am. F. Physiol. 177, $3_{3} 3$.

Hill, R. (196I). In World Review of Nutrition and Dietetics. Vol. 3, p. 145. [G. H. Bourne, editor.] New York: Hafner Publishing Corp.

Kimberg, D. V., Schachter, D. \& Schenker, H. (1961). Am. F. Physiol. 200, 1256.

Lemaire, R. \& Bronner, F. (1963). Fedn Proc. Fedn Am. Socs exp. Biol. 22, 553.

Luick, J. R., Boda, J. M. \& Kleiber, M. (1957). Am. F. Physiol. 189, 483.

Manston, R. (1964). Br. vet. F. 120, 365 .

Milhaud, G. Remagen, W., Gomes de Matos, A. \& Aubert, J.-P. (1960). Revue fr. Etud. clin. biol. 5, 254. Simesen, M. G., Lunaas, T., Rogers, T. A. \& Luick, J. R. (1962). Acta vet. scand. 3, 175.

Watson, D. \& Rogers, J. A. (1963). Clinica chim. Acta 8, I68. 